\title{
Immunodeficiency due to a late component of complement deficiency
}

INSERM

\section{Source}

INSERM. (1999). Orphanet: an online rare disease and orphan drug data base.

Immunodeficiency due to a late component of complement deficiency. ORPHA:169150

Immunodeficiency due to a late component of complement deficiency is a primary

immunodeficiency due to an anomaly in either complement components $\mathrm{C5}, \mathrm{C6}, \mathrm{C7}, \mathrm{C} 8$

or C9 and is typically characterized by mening itis due to often recurrent mening ococcal infections. The prognosis is generally favorable. 